\title{
JĘZYK JAKO ELEMENT ŚWIADOMOŚCI SPOLECZNEJ (NA PRZYKŁADZIE POLSKI PO 1918 ROKU) ${ }^{1}$
}

Słowa klucze: świadomość społeczna, świadomość językowa, ideologie językowe, okres międzywojenny, historia języka polskiego

Keywords: social consciousness, linguistic consciousness, language ideologies, the interwar period, history of Polish

Pojęcie świadomości społecznej służy w socjologii do opisu funkcjonowania pewnych zjawisk, wartości, interesów ważnych dla mniejszych czy większych grup społecznych. Odwołania do tego pojęcia znajdziemy również w polskich pracach językoznawczych, jak też odwołania - bez użycia określenia społeczna - do świadomości pewnej wyodrębnionej przez badacza grupy (np. polszczyzna w świadomości: studentów, mieszkańców wsi vs. miasta, mniejszości etnicznej itp.).

W artykule wyjdziemy od socjologicznego ujęcia świadomości społecznej jako wspólnoty przekonań i postaw. Została ona zdefiniowana przez Stanisława Ossowskiego jako:

pojęcia, obrazy, przekonania i oceny, które są mniej lub więcej wspólne ludziom pewnego środowiska i które w świadomości poszczególnych jednostek umacnia wzajemna sugestia, umacnia przekonanie, że dzielą je również inni członkowie tej samej grupy (Ossowski 1957: 11).

1 Artykuł jest zmienioną i uzupełnioną wersją odczytu wygłoszonego w styczniu 2016 r. na posiedzeniu Komisji Językoznawstwa Oddziału PAN w Krakowie. 
Marek Ziółkowski zwraca uwagę na dwie podstawowe warstwy świadomości społecznej. Pierwsza warstwa to indywidualne przekonania ludzi komunikujących się ze sobą. Drugą warstwę stanowią „mowa, pismo, obraz i czyn”, a zatem wszystkie przekazy komunikacyjne, począwszy od błahych codziennych rozmów, przez debaty intelektualne, literaturę, prasę, reklamę, po mniej lub bardziej oficjalne uroczystości. Właśnie ich wagę podkreśla socjolog, wyróżniając je nie jako rzeczywisty wyraz postaw i opinii, ale ze względu na fakt, że mogą one wywierać wpływ na przekonania innych ludzi (Ziółkowski 2015: 50-51; zob. też Sztompka 2009: 293-299).

Rola języka w świadomości społecznej nie ogranicza się do bycia narzędziem przekazu, ,instrumentem idei”, jak nazywa go Piotr Sztompka (ibid.: 288). Język zajmuje tu ważne miejsce jako sama idea, a więc i przedmiot oceny. W antropologii lingwistycznej panujące $\mathrm{w}$ określonych społecznościach postawy, opinie, przekonania lub teorie dotyczące języka określane są mianem ideologii językowych (zob. Ahearn 2013: 33-35). W polskiej literaturze socjolingwistycznej Danuta Bartol-Jarosińska (1986) na oznaczenie „całości sądów i wyobrażeń o języku” wprowadziła pojęcie społecznej świadomości językowej. Sądy te i przekonania w ujęciu polskiego językoznawstwa są określane jednak najczęściej jako świadomość językowa, nakładając się na psycholingwistyczne rozumienie świadomości językowej jako zdolności do używania języka, kompetencji językowej (zob. Przybysz-Piwko 2005; Maćkowiak 2011: 27-44).

Świadomość społeczna jest wielopłaszczyznowa - cechuje małe grupy (środowiska), jak i większe: narody, obywateli globalnej wioski. Łączy postrzeganie języka jako wartości absolutnej z oceną poszczególnych elementów językowych i grup, które się nimi posługują. Dla jej badacza istotne jest nie tyle, które elementy są poprawne, pożądane, a które nie, ale dlacz ego - jakie są kryteria formułowanych ocen językowych. Świadomość wspólnoty języka podbudowuje tożsamość grupy, która jest powiązana najczęściej z jakimś terytorium, stąd też ważne są ograniczone geograficznie formy językowe (w tym regionalizmy, dialektyzmy), które pozwalają odróżnić tutejszych (naszych) od „niemców” (obcych). Również zmiany w systemie nazw własnych - tworzenie czy wybór określonych toponimów, antroponimów, choronimów, a także przesunięcia semantyczne - ujawniają społeczną wspólnotę przekonań co do ich wartości pozytywnej lub negatywnej.

Język obok terytorium i państwa jest jedną z częściej wymienianych cech narodu, choć nie niezbędną. Jednak zmiany w życiu społecznym, pojawienie się jakiegoś konfliktu, np. etnicznego, wymagają „określenia się”, samouświadomienia, często także językowego. Można przywołać tu przykład XIX-wiecznej historii, kiedy ruchy narodowościowe wykorzystywały kryterium językowe jako czynnik identyfikujący naród (w tym Polacy), jak i przykłady z najnowszej historii krajów bałkańskich i Europy Środkowo-Wschodniej (Bobrownicka 2006: 208-219; Gajda 2008; Lubaś 2009; Hobsbawm 2010; Iżykowska 2015).

„Ścisły związek między językiem a życiem narodu należy do prawd oczywistych, niezaprzeczonych. [...] Jest on rzeczywistym i najważniejszym dowodem odrębno- 
ści narodowej" - takimi słowami rozpoczynał Adam A. Kryński (1931: 7) pierwszy rozdział poradnika Jak nie należy mówić i pisać po polsku, którego pierwsza część ukazała się w 1920 r. Warto zwrócić uwagę na opinie językowe z okresu międzywojennego, których podłożem był wiek XIX. Nie tylko reprezentują one bowiem stan ówczesnej świadomości językowej, ale też obrazują ogólną świadomość społeczną Polaków, którzy w 1918 r. odzyskali własne państwo. Druga Rzeczpospolita to państwo $\mathrm{w}$ trakcie wewnętrznych procesów integracyjnych i ten aspekt należy podkreślić. Wcześniej przekonanie o ważności polszczyzny jako czynnika wspólnotowego pozwoliło kształtować nowoczesne polskie społeczeństwo bez wsparcia państwa narodowego.

Przedmiotem niniejszego artykułu jest społeczna świadomość językowa Polaków w okresie kilkunastu lat po odzyskaniu niepodległości, od roku 1918 do pierwszej połowy lat 30., kiedy żywotne jest jeszcze przekonanie o kulturowym i mentalnym zróżnicowaniu byłych zaborów. Świadomość językowa w dwudziestoleciu to zagadnienie historycznojęzykowe i możemy ją rekonstruować, dysponując wypowiedziami stosunkowo niewielkiej części społeczeństwa, przede wszystkim przedstawicieli ówczesnej inteligencji. Trzeba zaznaczyć, że analizy tego rodzaju, opierające się na ograniczonym materiale tworzonym przez ograniczoną grupę osób (np. „mniejszość piśmienną" w średniowieczu), wiążą się z wątpliwościami, czy nie jest to wyraz poglądów wąskiej grupy ludzi, a nie ogółu, jaki jest stopień językowej refleksji autora tekstu, czy mamy do czynienia z kreowaniem poglądów, ich narzucaniem, a nie z odpowiedzią na zapotrzebowanie społeczne (Maćkowiak 2011: 19-20; Sagan-Bielawa 2014: 68-69; Iżykowska 2015: 134). Konieczny jest dobór tekstów źródłowych, które można uznać za ważne dla szerzenia poglądów i kształtowania opinii publicznej.

Wydaje się, że postawy wobec polszczyzny po 1918 r. szerzyły się w dużym stopniu pod dyktando - opracowywanych i często wydawanych jeszcze przed I wojną poradników językowych, takich jak cytowany wyżej poradnik Kryńskiego ${ }^{2}$. Były one zestawieniem, jak głosił tytuł jednego z nich, „błędów najpospolitszych”, a więc takich form, które „się najbardziej upowszechniły, a przez to stały się najniebezpieczniejszymi dla czystości mowy naszej” (Czarkowski 1909/1920: 4), „najbardziej zagrażają czystości języka” (Krasnowolski 1919: 4), są „obce naturze języka polskiego" i mają "nieswojskie pochodzenie” (por. Kryński 1920: 1, 1931: 17). Większość z tych błędów miała powstać pod wpływem języków zaborców. Podobna tematyka poruszana była na łamach powstałych jeszcze przed odzyskaniem niepodległości czasopism „Poradnik Językowy” (od 1901 r.) i „Język Polski” (od 1913 r.) - w tym w działach listów do redakcji, w których powoływano się niejednokrotnie na opinię wspomnianego już A.A. Kryńskiego.

2 Poradnik Adama A. Kryńskiego powstał m.in. na podstawie cyklu publikowanego w lwowskim „Słowie Polskim” w latach 1908-1910. Druga jego część zawiera także przedruki wygłoszonych publicznych odczytów. 
Zagadnienia poprawności językowej, charakterystyka językowa grup społecznych, regionalnych czy etnicznych nie ograniczały się do wydawnictw językoznawczych. Ówczesna prasa codzienna, mająca różnych odbiorców i zasięg, zróżnicowana politycznie i światopoglądowo, także pokazuje pozycję polszczyzny w świadomości społecznej $j^{3}$. Po I wojnie światowej prasa odgrywała bardzo ważną rolę w kształtowaniu nowoczesnej opinii publicznej, rozwijające się radio nie miało jeszcze dużego zasięgu. Związek pomiędzy zachowaniami językowymi, rozumieniem normy językowej a innymi elementami świadomości społecznej podkreślali ówcześni inteligenci, ludzie nauki, dziennikarze, publikując na łamach prasy opinie, które moglibyśmy zamknąć stwierdzeniem antropologa, że w ocenach (ideologiach) językowych „chodzi o coś więcej niż tylko o język" (por. Ahearn 2013: 34).

Biorąc pod uwagę liczne odwołania do charakteru narodowego, duszy narodu, a również do ducha języka, natury języka, możemy stwierdzić, że w polskiej publicystyce okresu międzywojennego mamy do czynienia z psychologizującym portretowaniem narodu polskiego i jego języka, co odpowiada ideom Humboldta i Herdera - język wyraża ducha narodu. Władysław Tarnawski pisał w latach 30. XX w., że artykuły poruszające kwestie języka, które ma okazję czytać, są „prawdziwym zwierciadłem umysłów” i materiałem do badań „psychologii indywidualnej i dzielnicowej" (Tarnawski 1934b: 583).

Dopełnienie wizerunku dzielnicy pozaborowej - upowszechnianego na przykład w prasie - stanowiła mowa jej mieszkańców. Język miał odpowiadać ogólnej charakterystyce zaboru (Sagan-Bielawa 2014: 101-130). Jeśli więc Galicja była uznawana za serwilistyczną, to serwilistyczna musiała być też tamtejsza polszczyzna, czego wyrazem były liczne - rzeczywiste i pozorne - germanizmy. Jeśli Wielkopolsce przypisywano oszczędność i konkret, to potwierdzenia tych cech szukano również w języku. Taki sposób myślenia pokazywały też prowadzone w okresie międzywojennym terenowe badania socjologiczne nad świadomością mieszkańców Poznania (Znaniecki 1931) i Górnego Śląska (Chałasiński 1935), podczas których badacze m.in. otrzymywali - zbliżoną do opinii prasowych - charakterystykę językową współmieszkańców miejscowości, różniących się pochodzeniem etnicznym czy regionalnym.

Symboliczna była dominacja polszczyzny byłego zaboru rosyjskiego, a dokładniej Królestwa Polskiego i Warszawy jako stolicy. Przekonanie to podtrzymywało spopularyzowane przez Kryńskiego twierdzenie, że regionalizmy (czy prowincjonalizmy, jak wówczas je nazywano) pozostają poza odmianą, którą on nazywał językiem literackim ogólnym, ogólnym językiem polskim lub językiem ogólnie polskim, a jej podstawę normatywną widział przede wszystkim w Warszawie.

3 Tematyka językowa pojawia się np. w takich tytułach, jak „Czas”, „Ilustrowany Kurier Codzienny”, „Myśl Narodowa”, „Tygodnik Ilustrowany” (zob. Gabryś-Sławińska 2016), „Wiadomości Literackie", a także w dziennikach lokalnych. Niektóre artykuły prasowe były omawiane na bieżąco w „Poradniku Językowym” w dziale Co piszą o języku? 
Charakterystyczną dla tamtego okresu argumentację stanowiło uzasadnianie zróżnicowania języka podziałami zaborowymi. Skupienie na uproszczonym obrazie Polski złożonej z trzech rodzajów Polaków, byłych poddanych trzech obcych władców, pozostawiało na marginesie sprawę innych narodowości, mieszanej ludności Kresów Wschodnich, Pomorza i Górnego Śląska. Takiemu schematowi myślenia zostały podporządkowane również tradycyjne, starsze niż zabory, podziały dialektalne. Cechy właściwe polszczyźnie Warszawy „musiały” sięgać aż po północną Małopolskę, bo tam właśnie sięgała granica Królestwa Polskiego. Zróżnicowanie dialektu kulturalnego w Galicji rzadko docierało do świadomości ludzi z innych regionów; Kraków i Lwów według ich wyobrażenia powinny mówić tak samo. Łatwiej można było zaakceptować nowy wówczas zwyczaj nazywania wschodniej Galicji Małopolską Wschodnią, łącząc ją językowo, mentalnie i politycznie z historyczną Małopolską (ziemią krakowską).

Przekonanie, że granice wariantywności językowej nakładają się na granice zaborowe, było utrwalane przez nazewnictwo upowszechniane po 1918 r. paradoksalnie - z myślą o zacieraniu różnic zaborowych i głębszej integracji. O tych przemianowaniach pisał Michał Bobrzyński na łamach krakowskiego „Czasu”:

Niemogąc teraz dzielnic nazwać: austryacką, pruską i rosyjską szuka się dla nich nazw polskich i tryumfuje znalazłszy gotowe nazwy: Wielkopolskę, Małopolskę i Koronę! Niepytając o anachronizm historyczny, który w zastosowaniu tych nazw do dzielnic rozbiorowych leży, już się te nomenklatury zaczyna wprowadzać, już deklinuje się na wszystkie przypadki Małopolskę z Krakowem i Lwowem, ale bez Sandomierza i Lublina (Bobrzyński 1919: 1).

Bobrzyński ostrzegał, że granice nie zostaną przez to zniesione, ale zaniknie świadomość tradycyjnego podziału ziem polskich. Także Kazimierz Nitsch (1924) pisał ironicznie o Małopolanach „z Kołomyi lub choćby ze Lwowa”. Zwracał uwagę, odwołując się do własnych doświadczeń z życia naukowego, że nazwa Małopolska traci wyrazistość:

gdy chce się mówić o prawdziwej Małopolsce, tj. o dawnych województwach krakowskiem, sandomierskiem i lubelskiem [...], trzeba to wyraźnie zaznaczać (ibid.: 46).

Podobnie Wielkopolska utrwaliła się jako nazwa jednego zaboru, mimo że ziemie historycznej Wielkopolski należały częściowo do Królestwa Polskiego. Wielkopolanami nazywano na przykład delegatów Naczelnej Rady Ludowej, którzy w marcu 1919 r. spotykali się w Warszawie z Ignacym Paderewskim i Józefem Piłsudskim:

Wielkopolanie przestrzegają dość silnie swego dzielnicowego separatyzmu, bo twierdzą, że u nich są stosunki zdrowsze [...]. Nie chcą również brać z Królestwa urzędników, bo mówią, że widzą tu dużo próżniactwa, a mało obowiązkowości (O wojsko: 1). 
Historyczne nazwy Małopolska, b. Królestwo Polskie lub b. Kongresówka (rzadziej Mazowsze) i Wielkopolska oraz pochodne od nich nazwy mieszkańców zastępowały określenia kojarzące się z niewolą (jak Galicja, zabór) i stosowane były przez cały okres międzywojenny. Najbardziej popularne były w pierwszych latach po odzyskaniu niepodległości, kiedy dopiero kształtował się nowy podział administracyjny. Służyły one jako pożyteczne - z perspektywy ekonomii językowej - określenia byłych dzielnic zaborowych:

a wkońcu góruje nad salę z marszałkowskiego krzesła także Wielkopolanin p. Trąmpczyński, postać sympatyczna i typowa. Kieruje obradami bardzo uważnie i spokojnie; zawsze jednak w sprawach formalnych najwięcej rutyny i doświadczenia okazują posłowie „małopolscy” z dawnej Galicyi, którzy mają za sobą przeważnie wieloletnie parlamentarne tradycye i których zdania prezydyum często zasięga (Na sali: 1).

[...] powstaje wrzawa na ławach Wielkopolan, która trwa dłuższy czas. [...] Sprawa między Małopolską a Polską nie jest sprawą dzielnicową, trzeba ją oceniać ze stanowiska polityki Państwa względem jednej dzielnicy. [...] W Sejmie nie powinno się stawiać kwestyi tak, jakoby Małopolanie stawali na gruncie partykularyzmu dzielnicowego (Sejm walny: 2) .

To niezbyt precyzyjne nazewnictwo stosował A.A. Kryński w poradach poprawnościowych, przeciwstawiając zwyczaje językowe Galicjan ${ }^{6}$ (lub Małopolan) oraz Wielkopolan poczuciu językowemu „ogółu czytelników polskich”:

Słowa z przedrostkami przyimkowemi prze- i przy-, jak np. przechodzić i przychodzić, przepłacić i przypłacić, przykazać i przekazać i t. p.? - różniące się wyraźnie znaczeniem, bywają nieraz używane błędnie, jedne zamiast drugich, zarówno w mowie ustnej wielu jednostek w Małopolsce, jak i w piśmie, zwłaszcza w dziennikarstwie lwowskim (Kryński 1920: 286).

O „przypadkowych konstrukcjach zaborczych” pisał autor króciutkiej recenzji Mapy narzeczy polskich K. Nitscha z 1919 r., opublikowanej w krakowskim „Czasie”, podkreślając, że dzięki pracy dialektologa

4 Nazwy te zawierają stenogramy z posiedzeń sejmu, a także ustawy oraz rozporządzenia rządowe. Z czasem zastąpiły je nazwy województw, ale jeszcze do 1939 r. funkcjonowały nazwy firm, instytucji i organizacji typu: Centralna Małopolska Kasa Oszczędności we Lwowie, Związek Ociemniałych Żołnierzy na Województwo Małopolskie z siedzibą we Lwowie, Izba Aptekarska Małopolski Wschodniej.

5 Małopolska i Małopolanie pojawiają się w wypowiedziach posłów (Hermana Diamanda i Henryka Radziszewskiego), przytoczonych przez dziennikarza.

6 W drugim tomie poradnika pisał już o byłej Galicji (Kryński 1931).

7 Mieszanie tych przedrostków wynikało z południowokresowej redukcji nieakcentowanego $e$, o czym Kryński nie wspominał. 
nietylko [...] historyczna geografia, ale i żywa mowa ludowa protestuje przeciw płytkiemu utożsamianiu zaboru pruskiego z Wielkopolską a Galicyi z Małopolską (Nowe publikacje: 2).

Ale na łamach tego samego pisma znajdziemy także i przejawy owej „płytkiej” świadomości. Korespondent z sejmu donosił, że często rozlega się tam „wielkopolski twardy akcent” posłów z byłego zaboru niemieckiego, w tym Ślązaka Wojciecha Korfantego (Na sali: 1). O tzw. twardym akcencie i różnicach w wymowie pisał też w swoim amatorskim poradniku językowym dziennikarz i literat Jan Tadeusz Wróblewski, uwydatniając jednocześnie normotwórczą rolę Mazowsza:

Różne dzielnice Rzplitej przyswoiły sobie różną wymowę, a więc: Wielkopolska, Pomorze i Śląsk pod wpływem języka niemieckiego - przybrały (naogół biorąc) wymowę twardą i nieco chropowatą; Małopolska Zachodnia - pod wpływem tegoż języka niemieckiego, lecz w mniejszym stopniu - wymowę twardawą; Małopolska Wschodnia - pod przeważającym wpływem języka rusińskiego - nieco przeciągłą; Kresy Wschodnie i Wileńszczyzna - pod wpływem języka rosyjskiego - miękką i śpiewną. Mazowsze zaś z b. Kongresówką najmniej uległo pod tym względem wpływom języków b. zaborców, zachowując wymowę ogólno-polską, jaką zresztą posiłkują się rodacy nasi i w innych dzielnicach Polski wychowani, lecz odporniejsi na wpływy wymowy otoczenia (Wróblewski 1926: 122).

Wróblewski wzorem Kryńskiego przypisywał germanizmy określonym dzielnicom: „Swoją kawę, swoje dwa kufle piwa wypiłem. Tak mówią w Mało- i Wielkopolsce, popełniając zwykły germanizm" (ibid.: 38$)^{8}$.

Kształtowanie się nowego podziału Małopolska - Mazowsze - Wielkopolska można zaobserwować także na przykładzie „Poradnika Językowego”. W jednym z zeszytów z 1920 r. omawiano „nowotwory” zaistnieć (np. zaistnieją warunki) i cło$w y$, pochodzące z edyktów sądowych - jak pisał autor - małopolskich, czyli m.in. z Przemyśla, Sambora, Czortkowa, Brzeżan i Stanisławowa (PJ 1920: 24-25). W innej językowej opinii postawiono znak równości pomiędzy Kongresówką a Mazowszem:

Nie chcielibyśmy, aby się i do języka wkradł partykularyzm tego charakteru, że to, jak się mówi w Warszawie albo w ogólności na Mazowszu (b. Kongresówka), jest decydujące (PJ 1927: 41).

Ujednolicenie polszczyzny ogólnej i usuwanie wariantów jako wpływu obcego uznawano za działania służące integracji Polaków. Argumentowano, że porozumie-

8 Por. fragment poradnika Antoniego Krasnowolskiego (1919: 78), który rzadko uzasadniał używanie germanizmów czy rusycyzmów różnicami regionalnymi: „Rano wypiłem swoją kawę, a wieczorem swoje dwa kufle piwa. Jest to germanizm. Ma to niby znaczyć, że taka jest moja zwyczajna porcja albo wogóle moje przyzwyczajenie. Ale po polsku tak się nie mówi; zaimek swój jest tu zbyteczny [...]". 
nie i jedność w języku są „dla życia narodowego przydatniejsze niż wielobarwność” (Magiera 1920: 21). Jako wyraz „jeszcze dalej posuniętej unifikacji, jeszcze mocniej i ściślej zjednoliconej kultury narodowej” przedstawiano prace nad ujednoliceniem wymowy scenicznej (Klich 1927: 8). Integracja językowa miała wymiar praktyczny i symboliczny. Zdaniem Floriana Znanieckiego, badającego przemiany społeczne w Poznaniu, dla żyjących obok siebie autochtonów i przybyszów z innych regionów oczywista była potrzeba dążenia do przynajmniej powierzchownej harmonii, której elementami miały być wzajemny szacunek, poszanowanie godności, nierażenie cudzych uczuć i posługiwanie się wspólnym językiem „na pewnym poziomie estetycznym i gramatycznym” (Znaniecki 1931: 84-85). Jak uzyskać ową harmonię? Znaniecki stwierdzał:

Z punktu widzenia samego współżycia ludności poznańskiej jest to społecznie obojętne, czy np. ujednostajnienie języka ma się dokonać drogą przyswojenia właściwości mowy poznańskiej przez przybyszów, czy też wyzbycia się tych właściwości przez Poznańczyków: zasadniczem jest, że to ujednostajnienie jest wogóle odczuwane jako coś pożądanego (ibid.: 85).

Choć na poziomie ogólnych postulatów panowała zgoda, ścierały się różne wizje językowej integracji. Międzydzielnicowe konflikty przejawiały się właśnie w odmiennym pojmowaniu roli polszczyzny regionalnej - jako wyrazu bogactwa językowego, narzędzia asymilacji lub przeszkody w pełnej integracji. Zarówno orędownicy zachowania różnorodności terytorialnej języka, jak i zwolennicy niwelowania wariantywności i wprowadzenia jednolitej normy językowej widzieli stanowisko przeciwne jako zagrożenie dezintegrujące polskie społeczeństwo, wypełniając popularne wówczas pojęcia partykularyzm, separatyzm, prowincjonalizm różnymi treściami.

Traktowany przez jednych jako warunek utrzymania wspólnoty językowo-kulturowej puryzm językowy przyczyniał się jednocześnie do powstawania nowych antagonizmów, miał bowiem charakter egocentryczny ${ }^{9}$. W Megalomanii narodowej Jan Stanisław Bystroń nazywał „nietolerancją językową” zjawisko negatywnego wartościowania polszczyzny regionalnej Poznania przez ludność napływową, uznającą swój język za wzorzec (Bystroń 1924/1995: 71). Przed taką postawą lekceważenia i pogardliwego traktowania innej niż własna mowy mieszkańców Pomorza czy Śląska przestrzegał K. Nitsch (1922), pisząc, że działalność polskich „cywilizatorów” doprowadzi do odwrócenia się Kaszubów i Ślązaków od Polski. I Nitsch, i Bystroń zauważali, że u podłoża tych postaw leży - charakterystyczna dla świadomości społecznej wielu wspólnot - pierwotna skłonność do uznawania swojego języka za „pierwszy, jedynie prawdziwy” (Bystroń 1924/1995: 20) i do uznawania odmienności mowy za przejaw obcości, niższości czy nawet wrogości. Krytykując, nazywano taką postawę 
„prowincjonalnym patriotyzmem językowym” ${ }^{10}$, mówiono o „prowincjonalnych poprawnościowcach” (JP 1925: 13), „osobach prowincjonalnie myślących” (PJ 1930: 77). Warto zauważyć, że również dla osób niechętnych nadmiernemu zróżnicowaniu polszczyzny, które stawiały znak równości między prowincjonalizmami („nieznanymi językowi ogólnopolskiemu”, jak pisał Kryński) a błędami językowymi, prowincjonalność oznaczała ciasnotę poglądów i niski poziom świadomości językowej.

Sądy językowe odwołują się do utrwalonych pojęć, wspólnych doświadczeń i wartości, ale na poziomie jednostki często okazują się sprzeczne, wykluczają się. Za taki przykład mogą posłużyć oceny - innowacyjnej na początku XX w. - eliminacji form żeńskich nazwisk na -owa, -ówna itp. Piętnowano ją jako zjawisko narzucone z zewnątrz, co było poglądem „bezpiecznym”, bo odwołującym się do doświadczenia życia pod zaborami. Ale w zależności od wiedzy językowej krytykującego, a może bardziej od jego osobistych antypatii czy sympatii, pojawienie się takiej tendencji tłumaczono - z pełnym przekonaniem - albo wpływem niemieckim, albo żydowsko-niemieckim, albo rosyjskim (por. Czarkowski 1909/1920: 46; PJ 1919: 85; Wróblewski 1926: 32; Obrazek: 27).

Świadomość społeczna wydaje się bagatelizować rzetelność sądów, kształtowana jest bowiem i na poziomie wiedzy - w tym wiedzy naukowej - i na poziomie opinii (Sztompka 2009: 297-298; Ziółkowski 2015: 53-55). Ta druga może wynikać z pewnej wiedzy, ale jej podstawową cechą nie jest zgodność z rzeczywistością, prawdziwość sądów, ale przekonanie, że są to poglądy podzielane przez większość (tzw. opinię publiczną). Takie przekonanie o powszechności pewnych postaw wyraża autor poniższych wypowiedzi:

Dla tego też i takie okazy, jak: przedkładać i przedłożyć ['przedstawić', np. projekt M.S.-B.] sztucznością swojej budowy rażą i razić muszą poczucie językowe większości Polaków, nie przywykłych do wzorów niemieckich i niemieckiego myślenia, a wciąganie podobnych słów do mowy ogólnej nie da się niczym usprawiedliwić (Kryński 1920: 137).

Niema dziś - można śmiało powiedzieć - ani jednej osobistości pośród inteligientnych warstw narodu, któraby nie podzielała utyskiwań nad niepoprawnością dzisiejszego języka (Kryński 1931: 29).

Twierdzenia wykluczające inne warianty, akcentujące typowość i powtarzalność zaobserwowanych zachowań językowych, sugerujące posiadanie pewnej wiedzy na dany temat, np. „nikt tak nie mówi i nie pisze” (JP 1928: 120), „po użyciu tej ostatniej formy od razu poznajemy...” (JP 1949: 233), „czytam nagłówek listu i od razu wiem, skąd przyszedł" (Wasylewski 1930/1957: 120), ,jak się nie po raz pierwszy okazuje” (JP 1927: 31), można uznać za przejaw naiwnego realizmu, założenia, że „rzeczywistość jest taka właśnie, jaka jest, i każdy (normalny) człowiek powinien ją postrzegać

10 Tak pisał Artur Passendorfer (1911: 65) jeszcze przed zjednoczeniem zaborów. 
tak samo" (Ziółkowski 2015: 55). Badając świadomość społeczną, w tym świadomość językową, spotykamy się właśnie ze światem naiwnego realizmu, w którym dużą rolę odgrywają stereotypy z charakterystycznymi dla nich uproszczeniami, ambiwalencją, emocjami, skłonnością do przejaskrawień, a nawet fałszowania rzeczywistości (Quasthoff 1998: 12-13; Sztompka 2009: 300).

Stereotypy społeczne wykorzystuje, podtrzymuje i utrwala m.in. twórczość satyryczna. Przejaskrawiona, zgodnie ze specyfiką gatunku, charakterystyka Polaków z trzech zaborów i ich języka pojawiała się w utworach satyrycznych po $1918 \mathrm{r}$. Przedrukowywały je i komentowały „Język Polski” i „Poradnik Językowy” (zob. Warszawszczyzna; Rozmaitości; Co piszą: 183). Jedna z tego rodzaju opowiastek dowodzi na przykład, utrwalając stereotyp, że prowincjonalizmy w języku jej bohaterów (Galicjanina, Poznaniaka i Królewiaka) to po prostu błędy, których należy unikać:

A morał trochę komicznej tej historii jasny: Zamiast wzajemnie się wyśmiewać i szydzić, starajmy się lepiej poznać swe błędy i przez wzajemne zetknięcie się oczyścić język ze szpetnych naleciałości prowincjonalnych (Rozmaitości: 15).

Istotę międzydzielnicowych antagonizmów językowych i rolę polszczyzny w procesach integracyjnych ujmowała żartobliwa stylistyka felietonów $\mathrm{Na}$ końcu języka Stanisława Wasylewskiego:

[...] w takim jednym przydechu czy nazweczce skrył się cały symbol różnicy szczepowej czasem, towarzyskiej często tylko i zwyczajowej. U nas inaczej, u nas najlepiej! Coup de mot - coup de foudre!

Zastępuje i symbolizuje całą odrębność życia szkoły i wychowania, i kodeksu obyczajowego, jest wykładnikiem różnic dzielnicowych, sygnałem ostrzegawczym, który demaskuje „innorodca” lub hasłem porozumienia, które łączy dzielnice (Wasylewski 1930/1957: 121).

Felietony Wasylewskiego pokazywały też Warszawę jako źródło puryzmu egocentrycznego, np.:

Stosunkowo najskuteczniej działa w dziedzinie ujednolicenia języka wojsko, potem kolej i szkoła. [...] We wszystkich tych dziedzinach spieszy z pomocą cała armia rewizorów z Warszawy niosąc w najgłębsze prowincje ideał mody, obyczaju, słowa, frazesu. Choć czasem pełni rolę dentystów wyrywających bez bólu zdrowe zęby z paszczęki (ibid.: 9-10).

Zbliżone opisy znajdujemy w międzywojennej prasie codziennej, w czasopismach kulturalnych, w poradnikach językoznawczych, w publicystyce uniwersyteckich profesorów. Również tam ty pow y inteligent warszawski pojawiał się jako ten, który raczej nie upowszechnia poprawnej polszczyzny, ale narzuca wszystkim swoje zwyczaje językowe: 
Osobistości te za stały swój obowiązek uważają udowadnianie, że tylko w Warszawie mówi się poprawnie (czyli po warszawsku: prawidłowo = rosyj. prawilno) po polsku (Birkenmajer 1923: 90).

Wybitny uczony miejscowy [warszawski - M.S.-B.] piętnował szereg wyrażeń, które uznawał za niepoprawne. [...] Oto obrazek typowy, który przypomina się nieraz przy lekturze różnych artykułów językowych w prasie warszawskiej. Chyba tylko w Warszawie mogło się zdarzyć to, co mnie spotkało. W książce naukowej, po ostatniej korekcie autorskiej, pozmieniano mi takie formy nieodmienne, jak bitwa pod Bosworth lub Geoffrey z Monmouth na odmienne (Bosworthem, Monmouthu). Tam i korektorzy potrafią być dyktatorami. Oni lepiej wiedzą... (Tarnawski 1934a: 546).

O wpływie innego, równie popularnego stereotypu społecznego można mówić w wypadku opinii na temat stanu polszczyzny urzędowej. Jak bowiem głosili bohaterowie satyrycznego wierszyka, „wszystkiemu, Panie, winni są ci Galicjanie...” (Warszawszczyzna: 127). Po roku 1918 powszechne było utożsamianie całej sfery urzędniczej z dawną biurokracją Austro-Węgier, a ważnym elementem tego obrazu były kalki z języka niemieckiego, np. wodpowiedzi na..., w przypuszczeniu przychylnego załatwienia, przydzielony do mniejszych władz polskich, rozpisać wybory, wykorzystać 'wyzyskać', w międzyczasie, bank dla handlu i przemysłu, szukać za czymś. Wynajdowane w prasie i w drukach formy - zapożyczone „oczywiście jako towar wiedeński” (por. Kryński 1931: 63) - miały zdradzać autorstwo biurokraty z Galicji:

Zadowolenie, jakie odczuwamy z powstania nowego polskiego zakładu państwowego mącą jednak błędy językowe, wskazujące niedwuznacznie, że formularz ten układał były urzędnik austrjacki (Seredyński 1919: 83).

[...] znać w nich [dekretach - M.S.-B.] biurokratę galicyjskiego czystej wody, który drży przy każdym wyrazie, aby przypadkiem duch biurokratyczny nie uleciał z jego mozolnych referatów (PJ 1919: 25).

Z treści wynika, że to podanie urzędnika związanego z b. władzami krajowymi w Galicji (PJ 1921: 58).

Czasownik zastępować, użyty w tem znaczeniu ${ }^{11}$, pobudza warszawiaków i w ogólności rdzennych mieszkańców dawnego Królestwa Polskiego do zastrzeżeń i dowodzeń, że w tym przypadku jest to germanizm, wprowadzony do języka polskiego przez mieszkańców dawnej Galicji (Łoś 1928: 162).

Trzeba podkreślić, że cytowany wyżej Jan Łoś jako uczony zaznaczał swój dystans do obiegowych opinii o „dawnych Galicjanach”, bez ich udziału upowszechniało się bowiem w polszczyźnie ogólnej wiele innych zjawisk językowych pierwotnie

11 Chodzi o zwrot „strony muszą być zastępowane przez adwokatów” użyty w notatce Polskiej Agencji Telegraficznej. 
stosowanych w jednej dzielnicy. Omówienie popularnego wówczas - a nieznanego dziś w języku polskim - germanizmu semantycznego zastępca podsumował następująco:

W tych razach niepodobna być prorokiem i przepowiedzieć, co zwycięży; rozstrzygający głos ma ogól, który u nas w praktyce niewiele dba o teorje językoznawcze (ibid.: 164).

Najczęściej jednak dziennikarz czy felietonista, pisząc o „typowym obrazku”, sugerował, że jego przykład to nie pierwszy, ale kolejny z wielu przypadków („całej armii”), dowodzących, że Kongresówka, Galicja lub Wielkopolska są właśnie takie, a nie inne - $\mathrm{i}$ jest to wiadome. Mieszczące się w konwencji felietonu uproszczenia, niedopowiedzenia, przerysowanie cech, zwłaszcza kiedy pojawiały się w publikacjach autorstwa profesora uniwersytetu, mogły być uznawane przez czytelnika za niepodważalny fakt, przyjmowane jako ważna, wartościowa wskazówka i powtarzane. W ten sposób w odrodzonym państwie kształtowały się i ścierały poglądy na temat stanu polszczyzny.

Te czasami kłócące się z wiedzą naukową i upraszczające twierdzenia „ogółu” warto badać. Oprócz specjalistycznej normalizacji języka - za którą odpowiedzialni są m.in. językoznawcy i szkoła - kierunek rozwoju języka wyznacza również „językowa i ogólnokulturowa świadomość danej społeczności”, której znaczenie podkreślała Irena Bajerowa (200o). Procesy integracyjne okresu międzywojennego sprzyjały ograniczeniu wariantywności w języku polskim jako zbędnej, a nawet szkodliwej cechy „dzielnicowej”. W świadomości społecznej dzielnicowy, partykularny charakter miały również same dążenia normalizacyjne (Warszawa jako ośrodek normalizacji, Galicja jako jej opozycja), m.in. za sprawą działalności takich językoznawców, jak Kryński i Nitsch, kojarzonych z określonym zaborem.

Pozycja języka - lub jego odmian - w świadomości społecznej nie musi być stała. Istnieje pewna tradycja, czego przykładem jest manifestowanie przywiązania Polaków do „ojczyzny-polszczyzny”, a jednocześnie następuje modyfikacja przekonań i postaw wobec języka. Decydują o tym takie wydarzenia, jak budowa państwa, utrata i odbudowa niepodległości, ale również zjawiska o skali globalnej, natury politycznej, ekonomicznej, kulturowej i technologicznej - od wynalezienia druku po powstawanie nowych kanałów komunikacji. W ostatnich latach na stosunek do polszczyzny wpływa zyskujący na popularności dyskurs tożsamościowy. Można by zakładać, że w zglobalizowanym świecie stare hasła stracą na popularności, pozostając poza obszarem zainteresowania młodszych pokoleń. Ich żywotności w Polsce dowodzą powracające - a więc zachowane w świadomości społecznej - odwołania do poczucia tożsamości Polaków, często są to odwołania właśnie do okresu zaborowego i Drugiej Rzeczypospolitej, kiedy nie mówiono o tożsamości narodowej bez polszczyzny. Rola języka w tym dyskursie jest warta obserwacji. 


\section{Źródła}

Birkenmajer J., 1923, Wyjaśnienia do „ęzyka małopolskiego”, „Język Polski” VIII, s. 89-91. Bobrzyński M., 1919, O zespoleniu dzielnic Rzeczypospolitej, „Czas” LXXII, nr 185, s. 1.

Co PISzĄ: Co piszą o języku?, „Poradnik Językowy” 1934, nr 10, s. 181-183.

Czarkowski L., 1909/1920, Słowniczek najpospolitszych rusycyzmów, Wilno.

JP 1925-1949: „Język Polski” X-XXXIX, działy: Odpowiedzi na pytania, Odpowiedzi Redakcji.

KLICH E., 1927, Jak mówić po polsku na scenie?, „Kurier Poznański” nr 12, s. 8.

KrasnowOlski A., 1919, Najpospolitsze błędy językowe zdarzające się w mowie i piśmie polskiem, wyd. 3 popr., Warszawa.

KRYŃski A.A., 1920-1931, Jak nie należy mówić i pisać po polsku, cz. 1, 1920, cz. 2, 1931, Warszawa.

Ł[oś] J., 1928, Zastępować, zastępstwo, zastępca, „Język Polski” XIII, s. 162-164.

Magiera J., 1920, Porozumienie się językowe, „Poradnik Językowy” nr 12-13, s. 19-21.

NA SALI: Na sali sejmowej, „Czas” 1919, LXXII, nr 63, s. 1-2.

Nitsch K., 1922, O poszanowanie odrębności prowincjonalnych, „Język Polski” VII, s. 33-37.

Nitsch K., 1924, O nazwy dzisiejszych części Polski, „Język Polski” IX, s. 45-51.

Nowe PUbLIKACJe: Nowe publikacje, „Czas” 1919, LXXII, nr 287, s. 2.

O wојsко: O wojsko i nowych posłów, „Czas” 1919, LXXII, nr 58, s. 1.

OBRAZEK: Obrazek z życia TMJP (Jednanie członków a forma nazwisk żeńskich), „Język Polski” 1933, XVIII, s. 27-29.

Passendorfer A., 1911, Język literacki w Królestwie Polskim a w Galicji, „Poradnik Językowy" nr 11, s. 65-69.

PJ 1919-1930: „Poradnik Językowy” 1919-1930, XVI-XXV, działy: Zapytania i odpowiedzi, Roztrząsania.

Rozmaitości: Rozmaitości. Krótka rozmowa między Galicjaninem, Poznaniakiem i Królewiakiem, „Poradnik Językowy” 1931, nr 1, s. 14-15.

SEJM WALNY: Sejm walny. Dyskusya walutowa, „Gazeta Lwowska” 1920, CX, nr 12, s. 1-2.

SEREDYŃsKi M., 1919, Urzędowe uświęcanie błędów językowych, „Poradnik Językowy” nr 6, S. 83.

TARnAWSKi W., 1934a, Pro domo et pro lingua, „Myśl Narodowa” nr 37, s. 544-546.

Tarnawski W., 1934b, Pro Varsovia, „Myśl Narodowa” nr 40, s. 583-584.

WarszaWszczyzNa: Warszawszczyzna, „Język Polski” 1921, VI, s. 126-128.

WASYlEWSKI S., 1930/1957, Na końcu języka, Wrocław.

WróвLEwsкi J.T., 1926, 2000 błędów językowych, barbaryzmów, dziwolagów i nowotworów ze wszystkich dzielnic Polski zebranych wraz ze słowniczkiem jako też wzorki stylu urzędowego, Warszawa.

\section{Literatura}

Ahearn L.M., 2013, Antropologia lingwistyczna. Wprowadzenie, Kraków.

BAJERowa I., 2000, Tendencja do normalizacji jako główny czynnik rozwojowy polskiego języka ogólnego, [w:] K. Rymut, W.R. Rzepka (red.), Studia historycznojęzykowe 3. Rozwój polskiego systemu językowego, Kraków, s. 9-14.

BARTOL-JARosińsKa D., 1986, Świadomość językowa robotników warszawskich. Studium leksykalno-semantyczne, Warszawa. 
Bobrownicka M., 2006, Patologie tożsamości narodowej w postkomunistycznych krajach słowiańskich. Uwagi o genezie i transformacjach kategorii tożsamości, Kraków.

Bystroń J.S., 1924/1995, Megalomania narodowa, Warszawa.

ChaŁası́́ski J., 1935, Antagonizm polsko-niemiecki w osadzie fabrycznej „Kopalnia” na Górnym Śląsku. Studium socjologiczne, Warszawa [odb. z „Przeglądu Socjologicznego” 1935, t. 3].

Dubisz S., 1988, Między dawnymi a nowymi laty. Eseje o języku, Warszawa.

GABRYś-SŁAwIŃsKa M., 2016, Język jako wartość w „Tygodniku Ilustrowanym” w latach 1918-1928, „LingVaria” nr 2 (22), s. 279-294, [on-line:] http://dx.doi.org/10.12797.LV. 11.2016.22.18.

Gajda S. (red.), 2008, Tożsamość a język w perspektywie slawistycznej, Opole.

Hobsbawm E., 2010, Narody i nacjonalizm po 1780 roku. Program, mit, rzeczywistość, Warszawa.

IżY KOwsKA M., 2015, Język polski jako wartość w publicystyce śląskiej XIX wieku, [w:] J. Adamowski, M. Wójcicka (red.), Wartości w języku i kulturze, Lublin, s. 123-135.

Lubaś W., 2009, Polityka językowa, Opole.

Mас́кошіак K., 2011, U źródeł polskiej świadomości językowej (X-XV wiek), Poznań.

Ossowski S., 1957, Struktura klasowa w społecznej świadomości, Wrocław.

Przybysz-Pıw ко M., 2005, Świadomość językowa. Problem nie tylko lingwistyczny, „Poradnik Językowy" nr 7, s. 42-47.

Quasthoff U., 1998, Etnocentryczne przetwarzanie informacji. Ambiwalencja funkcji stereotypów w komunikacji międzykulturowej, [w:] J. Anusiewicz, J. Bartmiński (red.), Stereotyp jako przedmiot lingwistyki. Teoria, metodologia, analizy empiryczne, „Język a Kultura", t. 12, Wrocław, s. 11-30.

Sagan-Bielawa M., 2014, Dziedzictwo pozaborowe. Społeczna świadomość językowa Polaków w Drugiej Rzeczypospolitej, „Biblioteka LingVariów”, t. 18, Kraków.

SztompкA P., 2009, Socjologia. Analiza społeczeństwa, Kraków.

ZıóŁKowski M., 2015, Teoria socjologiczna a transformacja społeczeństwa polskiego, Warszawa.

Znaniecki F., 1931, Miasto w świadomości jego obywateli. Z badań Polskiego Instytutu Socjologicznego nad miastem Poznaniem, Poznań.

\section{Language as an element of the social consciousness (using the example of Poland after 1918) Summary}

This paper has been inspired by social sciences. According to Stanisław Ossowski, social consciousness is the sum of ideas, opinions and convictions shared by a society. Every community has the ability to construct its own language ideologies (denoted in Polish by the term świadomość językowa 'language awareness'). The paper describes how the part of social consciousness that is related to the language, was reflected in Polish press after the regaining of the independence. Attitudes towards variation and all the other linguistic phenomena seem to have been influenced by the previous partition of the country, and regional and political stereotypes. View of the language was based on both linguistic knowledge and the common opinion. The paper attempts to demonstrate that social consciousness consists largely of general and mutually exclusive opinions which a more detailed analysis does not support. Notwithstanding, these convictions do have an indirect influence on the development of the language. 